\title{
Gastric inhibitory polypeptide and effects of glycation on glucose transport and metabolism in isolated mouse abdominal muscle
}

\author{
F P M O'Harte, A M Gray and P R Flatt \\ School of Biomedical Sciences, University of Ulster, Coleraine, Co. Londonderry, BT52 1SA, UK \\ (Requests for offprints should be addressed to F P M O'Harte)
}

\begin{abstract}
This study investigates the effects of gastric inhibitory polypeptide (GIP) and glycated GIP (glucitol adduct of GIP) on glucose uptake and metabolism in muscle. Glycated GIP (molecular mass 5147.2 Da) was purified by HPLC following in vitro incubation under hyperglycaemic reducing conditions $(24 \mathrm{~h}$ at $\mathrm{pH} 7 \cdot 4)$. GIP $\left(10^{-10}-10^{-8}\right.$ $\mathrm{mol} / \mathrm{l})$ significantly stimulated $(1 \cdot 4-$ to $1 \cdot 5$-fold, $P<0 \cdot 001)$ 2-deoxy-D- $\left[1-{ }^{3} \mathrm{H}\right]$ glucose uptake in abdominal muscle pieces from 3- to 5-week-old lean mice compared with control incubations (without GIP). This stimulatory effect on glucose uptake at $10^{-10}-10^{-9} \mathrm{~mol} / \mathrm{l}$ was decreased by $13-20 \%$ following glycation of the peptide $(P<0 \cdot 05)$. GIP $\left(10^{-9}\right.$ and $\left.10^{-8} \mathrm{~mol} / \mathrm{l}\right)$ induced a stepwise $1 \cdot 4$ - to $1 \cdot 7$-fold increase $(P<0.01, P<0.001$ respectively) in $\left[{ }^{14} \mathrm{C}\right]$ glucose oxidation compared with controls. This
\end{abstract}

effect on glucose oxidation was diminished by $32 \%$ with $10^{-8} \mathrm{~mol} / 1$ glycated GIP $(P<0 \cdot 05)$. GIP $\left(10^{-9}\right.$ and $10^{-8}$ $\mathrm{mol} / \mathrm{l})$ induced a $1 \cdot 4$ - to $1 \cdot 8$-fold increase in $\left[{ }^{14} \mathrm{C}\right]$ glucose incorporation into muscle glycogen (glycogenesis) compared with controls. Glycated GIP $\left(10^{-8} \mathrm{~mol} / \mathrm{l}\right)$ exhibited a $41 \%$ decrease in glycogenic activity $(P<0 \cdot 01)$. GIP $\left(10^{-10}-10^{-8} \mathrm{~mol} / \mathrm{l}\right)$ stimulated lactate production in isolated abdominal muscle (1.2- to 1.3-fold, $P<0 \cdot 05)$; however glycated GIP did not exert a significant effect. This study demonstrates for the first time that GIP promotes glucose uptake, glucose oxidation and glycogenesis in muscle tissue. Furthermore, modification of GIP through glycation diminishes its biological effectiveness.

Journal of Endocrinology (1998) 156, 237-243

\section{Introduction}

Incretins are endogenous peptides released from the gastrointestinal tract into the circulation following a meal, which potentiate glucose-stimulated insulin secretion. Currently there are two well established incretin hormones, gastric inhibitory polypeptide (GIP; glucosedependent insulinotrophic polypeptide) and glucagon-like peptide-1(7-36)amide (tGLP-1). The forty-two amino acid GIP was initially isolated from porcine intestine for its ability to inhibit gastric acid secretion (Brown et al. 1970), but its most important physiological role resides in its insulinotrophic activity (Morgan et al. 1988). GIP acts under mild or moderate hyperglycaemic conditions through specific receptors on the pancreatic B-cell (Wheeler et al. 1995) to stimulate insulin secretion and enhance proinsulin gene expression (Andersen et al. 1978).

GIP secretion is stimulated from the endocrine $\mathrm{K}$ cells of the duodenum and jejunum by the active transport of macronutrients rather than just their presence in the gut lumen (Sykes et al. 1980). The most important stimuli for GIP release are carbohydrate (Sykes et al. 1980), fat and triglycerides (Krarup et al. 1985, Kwasowski et al. 1985) and proteins (Flatt et al. 1991). Oral glucose is absorbed from the small intestine through an active sodium- dependent transport mechanism resulting in a sharp rise in plasma immunoreactive GIP and insulin concentrations (Cataland et al. 1974). The secretory response to fats is greater and more prolonged than glucose and may reflect the fact that fat slows gastric emptying and thus provides an extended stimulus for GIP release (Penman et al. 1981, Pedersen 1994). Ingestion of protein alone is a relatively weak stimulus for GIP release, although nearly all amino acids possess some GIP-releasing activity (Flatt et al. 1991).

Studies of the biological activity of GIP have identified a number of extrapancreatic target tissues including stomach, adipose tissue and liver. GIP can inhibit gastric acid secretion in man but only at supra-physiological concentrations (Maxwell et al. 1980, Nauck et al. 1992). However, GIP has a number of other potentially important actions which mirror some of the effects of insulin. These include the stimulation of glucose uptake in adipocytes, increased synthesis of fatty acids and activation of lipoprotein lipase in adipose tissue (Eckel et al. 1979, Oben et al. 1991, Morgan 1996). Both exogenous and endogenous GIP promote plasma triglyceride clearance in response to oral fat loading, indicating that fat-induced GIP secretion plays a physiological role in lipid metabolism in adipose tissue (Ebert et al. 1991). In liver, GIP has been shown to enhance insulin-dependent inhibition of 
glycogenolysis (Elahi et al. 1986). GIP also reduces both glucagon-stimulated lipolysis in adipose tissue as well as hepatic glucose production (Hartmann et al. 1986).

The other major incretin hormone, tGLP-1, has been reported to have potent stimulatory effects on glucose oxidation, glycogen synthesis and lactate formation in rat skeletal muscle (Villanueva-Peñacarrillo et al. 1994) mediated through specific tGLP-1 receptors (Delgado et al. 1995). The present study was carried out to investigate the possible influence of GIP on glucose uptake and metabolism in skeletal muscle. Since recent studies in our laboratory have demonstrated that peptide hormones such as proinsulin and insulin can be glycated during the stages of synthesis and storage in secretory cells (Abdel-Wahab et al. 1996a, 1997), we have also investigated whether GIP can be glycated. A recent study demonstrated that modification of tGLP-1 through glycation reduces it effectiveness at promoting glucose uptake and utilization in isolated muscle tissue (O'Harte et al. 1997) and in this context it was of interest to examine the efficacy of the glycated form of the other major incretin hormone, GIP, on muscle glucose metabolism. The present study demonstrates for the first time that GIP promotes glucose uptake and metabolism in isolated muscle from mice and that glycation of GIP (glucitol adduct of GIP) reduces its biological activity in muscle in vitro.

\section{Materials and Methods}

\section{Reagents}

HPLC grade acetonitrile was obtained from Rathburn (Walkersburn, Scotland). Sequencing grade trifluoroacetic acid (TFA) was obtained from Aldrich (Poole, Dorset, UK). All water used in these experiments was purified using a Milli-Q Water Purification System (Millipore Corporation, Millford, MA, USA). Human insulin (E. coli recombinant) and sodium cyanoborohydride were obtained from Sigma (Poole, Dorset, UK). Human GIP was obtained from the American Peptide Company (Sunnyvale, CA, USA). Radiolabelled 2-deoxy-D- $\left[1-{ }^{3} \mathrm{H}\right]$ glucose, $\mathrm{D}-\left[\mathrm{U}^{14} \mathrm{C}\right]$ glucose and $\mathrm{L}-\left[1^{14} \mathrm{C}\right]$ glucose were obtained from Amersham Life Science (Amersham, Bucks, UK).

\section{Preparation of glycated GIP}

Human GIP $(50 \mu \mathrm{g})$ was incubated with $220 \mathrm{mmol} / 1$ D-glucose together with a 1000-fold molar excess of $\mathrm{NaBH}_{3} \mathrm{CN}$ (dissolved in $10 \mathrm{mmol} / \mathrm{l} \mathrm{NaOH}$ ) in $10 \mathrm{mmol} / 1$ sodium phosphate buffer $\mathrm{pH} 7 \cdot 4$ for $24 \mathrm{~h}$ at $37^{\circ} \mathrm{C}$ (total volume $1.0 \mathrm{ml}$ ). Control (non-glycated) GIP was prepared in the same manner except for the exclusion of glucose from the incubation mixture. The reaction was stopped by addition of $0.5 \mathrm{~mol} / 1$ acetic acid $(30 \mu \mathrm{l})$ and the sample mixture applied to a $(4.6 \times 250 \mathrm{~mm})$ Vydac $218 \mathrm{TP} 54$
(C18) analytical column (The Separations Group, Hesperia, CA, USA) and eluted at a flow rate of $1.0 \mathrm{ml} /$ min. The mobile phase consisted of solvent A: $0 \cdot 12 \%(\mathrm{v} / \mathrm{v})$ TFA in water; solvent B consisted of $0.1 \%(\mathrm{v} / \mathrm{v})$ TFA in $70 \%$ acetonitrile, $29.9 \%$ water. Elution profiles were monitored at $206 \mathrm{~nm}$ and peptide peaks collected by hand. GIP and glycated GIP were separated using linear gradients of $0 \%$ to $31.5 \%$ acetonitrile over $10 \mathrm{~min}$, followed by $31.5 \%$ to $45 \cdot 5 \%$ acetonitrile over $20 \mathrm{~min}$. Two major peaks were collected eluting after $16.7 \mathrm{~min}$ and $16.9 \mathrm{~min}$ corresponding to glycated GIP and GIP respectively. Fractions of glycated GIP were pooled, taken to dryness using a Speed-Vac (AES 1000 Savant, Life Sciences International, Runcorn, Cheshire, UK) and reconstituted in $0 \cdot 12 \%(\mathrm{v} / \mathrm{v})$ TFA/water. Glycated GIP was purified to homogeneity by repeated HPLC runs on a $(4 \cdot 6 \times$ $150 \mathrm{~mm}$ ) Supelcosil (C8) analytical column (Supelco Inc., Poole, Dorset, UK). GIP and glycated GIP were quantified by comparison of peak areas obtained from reversephase (RP)-HPLC with a standard curve using known concentrations of GIP.

\section{Electrospray ionization mass spectrometry (ESI-MS)}

Samples of GIP and glycated GIP for ESI-MS were dissolved in $100 \mu \mathrm{l} 0 \cdot 1 \%(\mathrm{v} / \mathrm{v}) \mathrm{TFA} /$ water and applied to the LC/MS using gradient elution HPLC (C18 column, $150 \times 2 \cdot 0 \mathrm{~mm})$. Samples $(10 \mu \mathrm{l}$ injection) were applied at a flow rate of $0.2 \mathrm{ml} / \mathrm{min}$, using a linear gradient from $0 \%$ to $90 \%$ acetonitrile over $10 \mathrm{~min}$ and holding at $90 \%$ acetonitrile for $10 \mathrm{~min}$. Mass spectra were recorded on a Finnigan Mat LCQ benchtop mass spectrometer (Finnigan Mat, Hemel Hempstead, Herts, UK) and spectra were obtained from the quadripole ion trap mass analyzer. Spectra were collected using full ion scan mode (400-1850 m/z mode) and UV absorbance (280 nM).

\section{Animals}

Male lean mice aged between 3 and 5 weeks were obtained from the Behavioural and Biomedical Research Unit, University of Ulster, Coleraine. The animals were housed in an air-conditioned room at $22 \pm 2{ }^{\circ} \mathrm{C}$ and were fed a standard rodent maintenance diet from weaning (3 weeks) (Specialist Diet Services, Witham, Essex, UK). Food and tap water were available ad libitum. Animals were killed by cervical dislocation and the abdominal muscle quickly excised. The muscle was dissected into 10 pieces of approximately $10 \mathrm{mg}$ each (accurately weighed) and used for either glucose uptake or metabolism studies.

\section{Glucose uptake studies}

Glucose uptake was monitored using tritiated 2-deoxy-D$\left[1-{ }^{3} \mathrm{H}\right]$ glucose $(0 \cdot 1 \mu \mathrm{Ci}$, specific activity $11000 \mathrm{mCi} /$ $\mathrm{mmol})$, and non-metabolisable $\mathrm{L}-\left[1-{ }^{14} \mathrm{C}\right]$ glucose $(0 \cdot 1 \mu \mathrm{Ci}$, 
specific activity $55 \mathrm{mCi} / \mathrm{mmol}$ ) to correct for 2-deoxy-D$\left[1-{ }^{3} \mathrm{H}\right]$ glucose uptake in the extracellular space. Incubations were performed in mini-scintillation vials (Fisons Scientific, Leicester, UK) containing $5 \mu$ of each radioisotope and $1.0 \mathrm{ml}$ Krebs Ringer bicarbonate buffer (KRBB, $118 \mathrm{mmol} / 1 \mathrm{NaCl}, 5 \mathrm{mmol} / \mathrm{l} \mathrm{KCl}, 25 \mathrm{mmol} / 1$ $\mathrm{NaHCO}_{3}, \quad 1.18 \mathrm{mmol} / 1 \quad \mathrm{MgSO}_{4} .7 \mathrm{H}_{2} \mathrm{O}, \quad 1.17 \mathrm{mmol} / \mathrm{l}$ $\mathrm{KH}_{2} \mathrm{PO}_{4}, 2.0 \mathrm{mmol} / 1$ sodium pyruvate, $1.28 \mathrm{mmol} / 1$ $\mathrm{CaCl}_{2}$ ) and $2 \%(\mathrm{w} / \mathrm{v})$ bovine serum albumin (BSA). Vials were stoppered (Subaseal, Gallencamp, Loughborough, Leics, UK) and placed in a shaking water bath (92 cycles $/ \mathrm{min})$ at $30^{\circ} \mathrm{C}$ and gassed $\left(95 \% \mathrm{O}_{2}: 5 \% \mathrm{CO}_{2}\right)$ for 20-25 min until the incubation medium reached $\mathrm{pH} 7 \cdot 4$. Test peptide (insulin or GIP, $10 \mu \mathrm{l}$ of 100 -fold concentration) and a freshly obtained pre-weighed piece of abdominal muscle were then added. Vials were stoppered and gassed $\left(95 \% \mathrm{O}_{2}: 5 \% \mathrm{CO}_{2}\right)$ for the initial $2 \mathrm{~min}$ of incubation. After a further $28 \mathrm{~min}$ incubation without further gassing, tissue pieces were removed, blotted thoroughly and hydrolysed in $0.5 \mathrm{ml} 1 \mathrm{~mol} / 1 \mathrm{NaOH}$ at $85^{\circ} \mathrm{C}$ for $60 \mathrm{~min}$. Samples were cooled and HiSafe II scintillation fluid $(5.0 \mathrm{ml}$, Fisons, Loughborough, UK) added and ${ }^{14} \mathrm{C} /{ }^{3} \mathrm{H}$ counted for $10 \mathrm{~min}$ using a dual count program (Wallac 1409 Liquid Scintillation Counter; Wallac Oy, Turke, Finland). Values for glucose uptake are expressed as d.p.m. uptake/mg wet weight muscle/h.

\section{Glucose oxidation studies}

Glucose oxidation was determined by measuring ${ }^{14} \mathrm{CO}_{2}$ production during muscle incubations. An aliquot $(5 \mu \mathrm{l})$ of D-[U- $\left.{ }^{14} \mathrm{C}\right]$ glucose (specific activity $298 \mathrm{mCi} / \mathrm{mmol}$ ) corresponding to $0.5 \mu \mathrm{Ci}$ radioactivity was added to miniscintillation vials containing $1.0 \mathrm{ml} \mathrm{KRBB}$ supplemented with BSA $2 \%(\mathrm{w} / \mathrm{v})$ and $10 \mathrm{mmol} / \mathrm{l}$ glucose. An inner tube containing a narrow strip of filter paper (Whatman No. 1) was placed in each vial which was then stoppered. Vials were placed in a shaking water bath at $37^{\circ} \mathrm{C}$ and gassed with $95 \% \mathrm{O}_{2}: 5 \% \mathrm{CO}_{2}$ for $20-25 \mathrm{~min}$ until the incubation medium reached $\mathrm{pH} 7 \cdot 4$. Test peptide (insulin or GIP, $10 \mu \mathrm{l}$ of 100-fold concentration) was added to each vial followed by a weighed piece of muscle tissue. The vials were stoppered, returned to the shaking water bath and gassed for an initial 2-min period. After a total of $60 \mathrm{~min}$ incubation, an aliquot $(100 \mu \mathrm{l})$ of $1 \mathrm{~mol} / \mathrm{l} \mathrm{NaOH}$ was injected through the rubber stopper directly onto the filter paper and the vials placed on ice for $5 \mathrm{~min}$ before removing the muscle pieces. The vials were again stoppered and $100 \mu \mathrm{l} 3 \mathrm{~mol} / \mathrm{l}$ perchloric acid were added through the stopper into the incubation mixture. The samples were incubated at room temperature for $60 \mathrm{~min}$ and the filter paper subsequently removed to a scintillation vial and $5 \mathrm{ml}$ HiSafe II scintillation fluid added prior to counting the ${ }^{14} \mathrm{C}$ for $10 \mathrm{~min}$ (Wallac 1409 Liquid Scintillation Counter). Values for glucose oxidation are expressed as nmol $\mathrm{CO}_{2}$ produced/mg wet weight muscle/h.

\section{Glycogen production studies}

Following completion of the glucose oxidation studies, muscle was removed from the vials and blotted before transfer to a fresh scintillation vial containing $1 \mathrm{ml} 1 \mathrm{~mol} / 1$ $\mathrm{KOH}$. These vials were capped and heated at $85^{\circ} \mathrm{C}$ for $30 \mathrm{~min}$ to hydrolyse the tissue. The hydrolysate was cooled and $2 \mathrm{ml} \mathrm{95 \%} \mathrm{ethanol} \mathrm{added} \mathrm{with} \mathrm{mixing.} \mathrm{After} 30 \mathrm{~min}$ at room temperature the samples were centrifuged at $2000 \boldsymbol{g}$ for $10 \mathrm{~min}$ (Beckman model J-6B centrifuge) and the supernatant discarded. The pellet was re-extracted twice with 95\% ethanol as above and the supernatants discarded. Sulphuric acid was added $(1 \mathrm{ml}, 1 \mathrm{~mol} / \mathrm{l})$ to the pellet in a screw-cap vial and heated to $85^{\circ} \mathrm{C}$ for $2 \mathrm{~h}$. Following cooling, approximately $0.6 \mathrm{ml} 5 \mathrm{~mol} / 1 \mathrm{NaOH}$ was added to neutralize the solution $(\mathrm{pH} 7 \cdot 0)$. Scintillation fluid $(5 \mathrm{ml}$ HiSafe II) was added to an aliquot $(0.5 \mathrm{ml})$ of the neutralised solution and ${ }^{14} \mathrm{C}$ counted for $10 \mathrm{~min}$ (Wallac 1409 Liquid Scintillation Counter). The glycogen production data are expressed as nmol glucose equivalents/mg wet weight muscle/h.

\section{Lactate assay}

The solution containing perchloric acid from the glucose oxidation studies (stored at $-20^{\circ} \mathrm{C}$ ) was neutralised $(\mathrm{pH}$ 7.0) with $5 \mathrm{~mol} / 1 \mathrm{NaOH}$ and appropriate dilutions used for the lactate determinations. Lactate analysis was performed using a colorimetric LDH-based enzymatic assay (Boehringer Mannheim, Mannheim, Germany, kit 256773). NAD reagent buffer $(2 \cdot 1 \mathrm{ml}$ containing $4.6 \mathrm{mmol} / 1 \mathrm{NAD}, 63 \mathrm{mmol} / 1$ glutamic acid, $0.5 \mathrm{~mol} / 1$ $\mathrm{Na}_{2} \mathrm{HCO}_{3}$ adjusted to $\mathrm{pH} 10 \cdot 0$ with $2 \mathrm{~mol} / 1 \mathrm{NaOH}$ ) was added to a known volume of neutralised sample which was mixed and divided into two $1.0 \mathrm{ml}$ fractions in separate cuvettes. LDH/GPT enzyme solution $(10 \mu \mathrm{l})$ or $\left(\mathrm{NH}_{4}\right)_{2} \mathrm{SO}_{4}(10 \mu \mathrm{l})$ was added to the test or blank sample respectively and, after inverting, both samples were left at $25^{\circ} \mathrm{C}$ for $15 \mathrm{~min}$. The absorbance of test versus blank samples was recorded at $340 \mathrm{~nm}$ on a spectrophotometer. The difference in absorbance readings was directly proportional to the amount of lactate in the sample. The concentration of lactate was calculated using the BeerLambert equation $(\mathrm{a}=\varepsilon$. c . l) where the molar extinction coefficient for NADH is $6.31 \times 10^{3}$. Lactate production was expressed as nmoles lactate/mg wet weight muscle/h.

\section{Statistical analysis}

Results are expressed as means \pm S.E.M. and values were compared using the Student's unpaired $t$-test. Groups of data were considered to be significantly different if $P<0 \cdot 05$. 


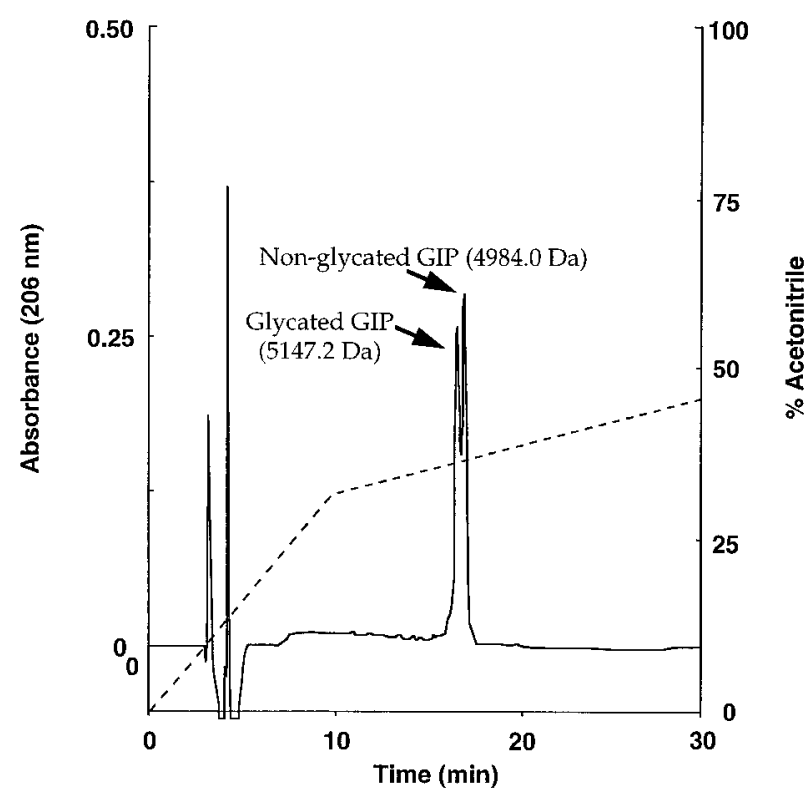

Figure 1 HPLC separation of GIP and glycated GIP on a Vydac C18 column $(4.6 \times 250 \mathrm{~mm})$. Glycated and non-glycated fractions were separated using linear gradients of $0 \%$ to $31 \cdot 5 \%$ acetonitrile over $10 \mathrm{~min}$ followed by $31 \cdot 5 \%$ to $45 \cdot 5 \%$ over $20 \mathrm{~min}$. Two major peaks were collected manually, purified to homogeneity by repeated HPLC chromatography and the molecular masses determined by ESI-MS. The observed mass for each species is indicated in parentheses.

\section{Results}

Figure 1 shows a typical RP-HPLC trace obtained for the separation of GIP and glycated GIP on a Vydac C18 column. Following purification by RP-HPLC (Supelcosil C8), the molecular masses of GIP $\left(M_{\mathrm{r}} 4984 \cdot 0\right)$ and glycated GIP $\left(M_{\mathrm{r}} 5147 \cdot 2\right)$ were determined by ESI-MS. The modified peptide contained a single glucitol adduct (+163.2 Da) corresponding to monoglycated GIP, which was used for subsequent glucose metabolism studies.

Table 1 shows the effects of human insulin on glucose uptake over the concentration range tested $\left(10^{-9}-10^{-7}\right.$ $\mathrm{mol} / \mathrm{l})$. Insulin stimulated glucose uptake in isolated mouse abdominal muscle pieces $(n=6)$ compared with control samples $(n=10$, no added insulin) in a dose-dependent manner. Furthermore, results for glucose oxidation indicate that insulin stimulates $(n=17)$ this process above control values $(n=17)$ in a dose-dependent fashion at $10^{-8} \mathrm{~mol} / \mathrm{l}$ and $10^{-7} \mathrm{~mol} / 1$.

Figure 2A shows the effects of GIP and glycated GIP on glucose uptake in isolated abdominal muscle. The stimulatory effect of $10^{-8} \mathrm{~mol} / \mathrm{l}$ insulin is included for comparison. GIP stimulated glucose uptake $(P<0 \cdot 001)$ over the concentration range tested $\left(10^{-10}-10^{-8} \mathrm{~mol} / \mathrm{l}\right)$ compared with controls (no additions). Glycation of GIP significantly reduced its biological activity by $13-20 \%$ compared with GIP.
Table 1 Effect of insulin $\left(10^{-9}-10^{-7} \mathrm{~mol} / \mathrm{l}\right)$ on glucose uptake and oxidation in isolated abdominal muscle pieces from mice. Results are expressed as means \pm S.E.M. for pairs of muscle from 3 to 5-week-old male mice ( $n=6-10$ for glucose uptake; $n=17$ for glucose oxidation)

\begin{tabular}{|c|c|c|}
\hline & $\begin{array}{l}\text { Glucose uptake } \\
\text { (d.p.m./mg tissue/h) }\end{array}$ & $\begin{array}{l}\text { Glucose oxidation } \\
\left(\mathrm{nmol} / \mathrm{CO}_{2} / \mathrm{mg}\right. \\
\text { tissue/h) }\end{array}$ \\
\hline \multicolumn{3}{|l|}{$\begin{array}{l}\text { Insulin concentration } \\
(\mathrm{mol} / \mathrm{l})\end{array}$} \\
\hline Control (no insulin) & $283 \pm 14$ & $0 \cdot 343 \pm 0 \cdot 042$ \\
\hline $10^{-9}$ & $396 \pm 55^{*}$ & $0 \cdot 486 \pm 0 \cdot 059$ \\
\hline $10^{-8}$ & $482 \pm 48^{* *}$ & $0.552 \pm 0.063^{* *}$ \\
\hline $10^{-7}$ & $663 \pm 76^{* * *}$ & $0.631 \pm 0.057^{\star \star *}$ \\
\hline
\end{tabular}

Figure 2B shows the effects of non-glycated and glycated peptides on glucose oxidation in isolated mouse abdominal muscle. GIP stimulated glucose oxidation over the concentration range $10^{-9}-10^{-8} \mathrm{~mol} / 1$ in a dosedependent manner compared with controls. Glycation of GIP significantly reduced its biological activity by $32 \%$ $(P<0.05)$ compared with non-glycated peptide at $10^{-8}$ $\mathrm{mol} / \mathrm{l}$. Furthermore, glycated GIP $\left(10^{-9}-10^{-8} \mathrm{~mol} / \mathrm{l}\right)$ failed to stimulate glucose oxidation above control values.

Figure $3 \mathrm{~A}$ shows the effects of GIP and glycated GIP on glycogen production in isolated abdominal muscle. GIP stimulated glycogenesis over the concentration range $\left(10^{-9}-10^{-8} \mathrm{~mol} / \mathrm{l}\right)$ compared with controls $(P<0 \cdot 01)$. Glycation of GIP significantly reduced its biological activity by $41 \%(P<0 \cdot 01)$ compared with the non-glycated peptide at $10^{-8} \mathrm{~mol} / 1$. Moreover, glycated GIP at $10^{-9}$ and $10^{-8} \mathrm{~mol} / \mathrm{l}$ failed to stimulate glycogen production above controls.

Figure $3 \mathrm{~B}$ shows the effects of GIP and glycated GIP on lactate production. GIP stimulated lactate production in isolated abdominal muscle over the concentration range tested $\left(10^{-10}-10^{-8} \mathrm{~mol} / \mathrm{l}\right)$ compared with controls. Glycation of GIP showed a tendency towards reduced biological activity compared with non-glycated peptide, but this reduction was not statistically significant. Glycated GIP at $10^{-8} \mathrm{~mol} / \mathrm{l}$ failed to stimulate lactate production above controls, whereas $10^{-9} \mathrm{~mol} / \mathrm{l}$ glycated GIP was stimulatory.

\section{Discussion}

Although the insulin-releasing action of GIP makes a major contribution to its metabolic role, direct effects of GIP at extrapancreatic sites, including stomach, liver and adipose tissue, have been suggested to contribute to the overall action of the hormone on post-prandial nutrient homeostasis (Fehmann et al. 1995). Our observations that 


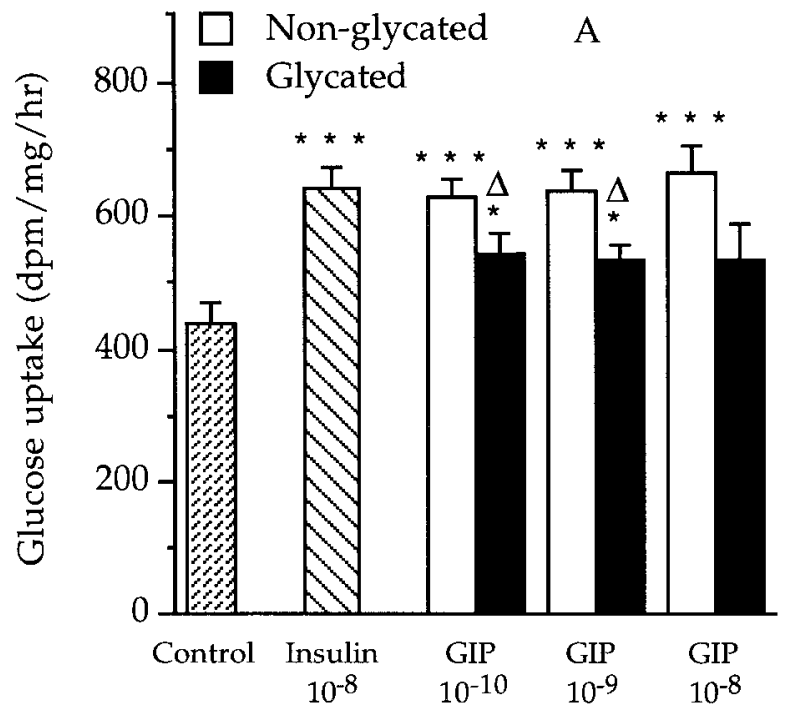

Peptide concentration ( $\mathrm{mol} / \mathrm{l})$

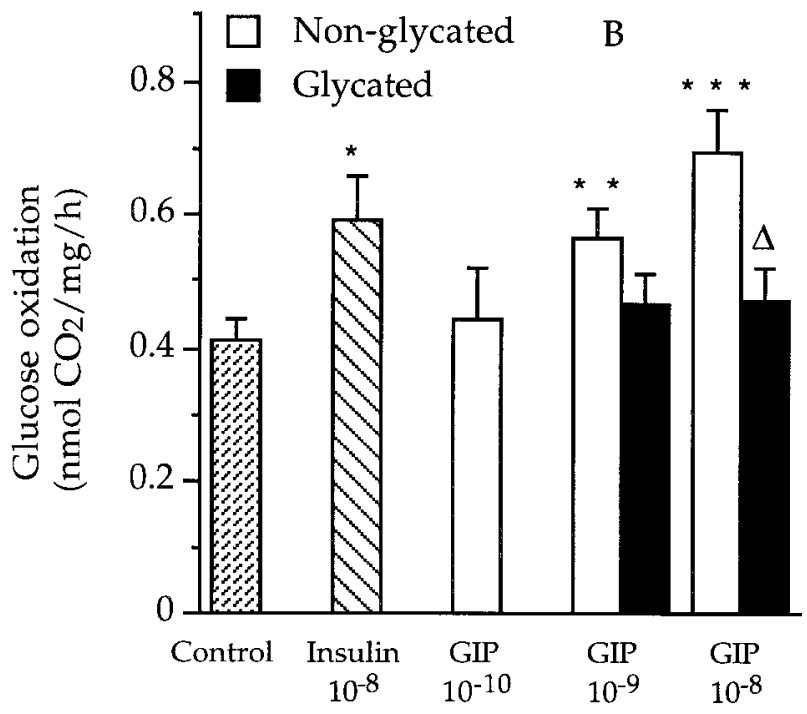

Peptide concentration (mol/l)

Figure 2 Effects of $10^{-8} \mathrm{~mol} / \mathrm{l}$ insulin and GIP and glycated GIP $\left(10^{-10}\right.$ to $\left.10^{-8} \mathrm{~mol} / \mathrm{l}\right)$ on (A) glucose uptake and (B) glucose oxidation in isolated mouse abdominal muscle. Results are expressed as means \pm S.E.M. for pairs of muscle from 3 to 5-week-old mice (glucose uptake: insulin $n=19$, GIP $n=19$, glycated GIP $n=10$; glucose oxidation: insulin $n=14$, GIP $n=15$, glycated GIP $n=10) .{ }^{*} P<0 \cdot 05,{ }^{* *} P<0 \cdot 01,{ }^{* * *} P<0 \cdot 001$ compared with control incubations (without added insulin). $\triangle P<0 \cdot 05$ compared with GIP at the same concentration.

GIP stimulates glucose transport, oxidation, glycogenesis and lactate formation in mouse abdominal muscle support this view. These findings are paralleled by observations of
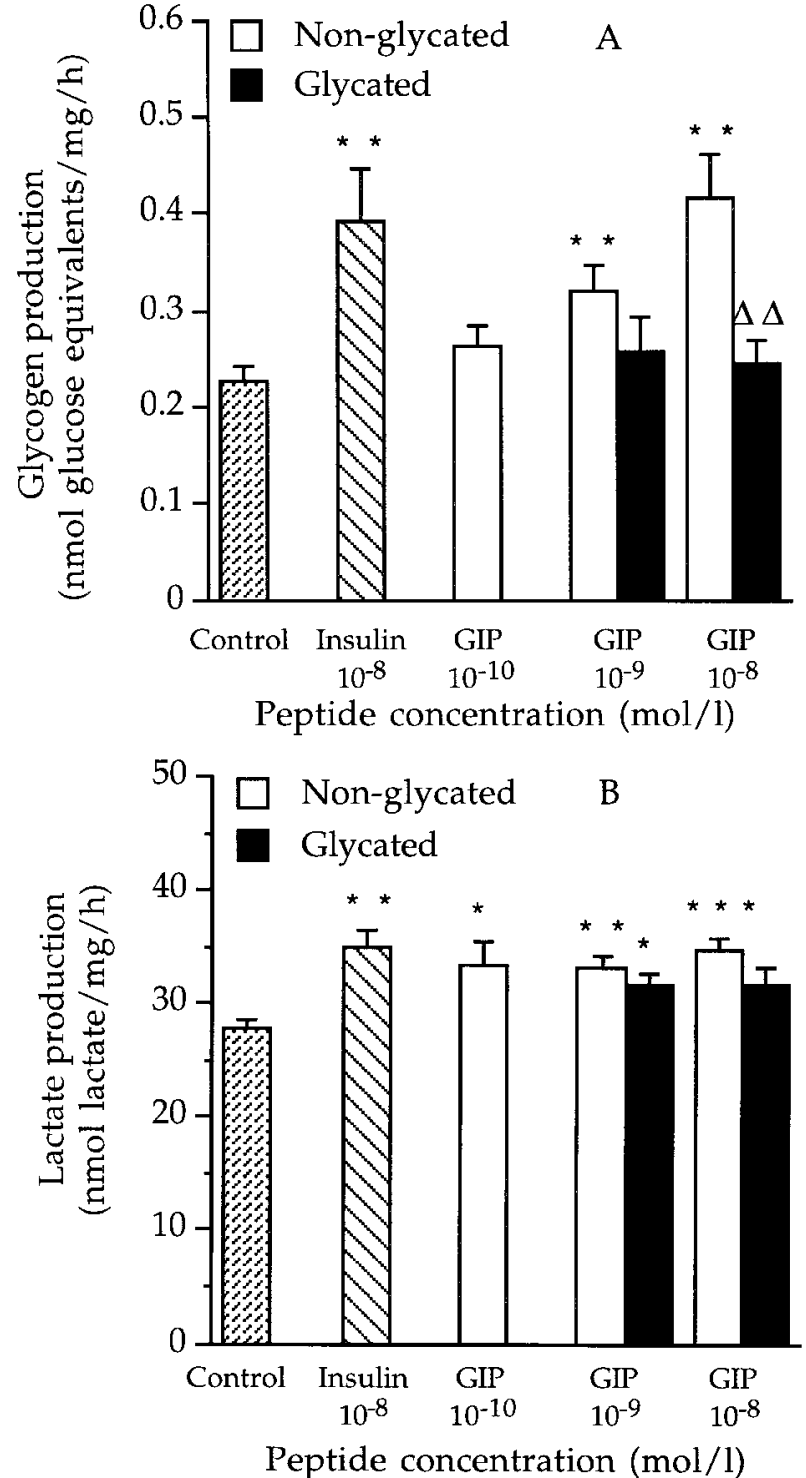

Figure 3 Effects of $10^{-8} \mathrm{~mol} / /$ insulin and GIP and glycated GIP $\left(10^{-10}\right.$ to $\left.10^{-8} \mathrm{~mol} / \mathrm{l}\right)$ on (A) glycogenesis and (B) lactate production in isolated mouse abdominal muscle. Results are expressed as means \pm S.E.M. for pairs of muscle from 3 to 5-week-old mice (glycogenesis: insulin $n=13$, GIP $n=13$, glycated GIP $n=9$; lactate production: insulin $n=14$, GIP $n=15$, glycated GIP $n=10) .{ }^{*} P<0 \cdot 05,{ }^{* *} P<0 \cdot 01,{ }^{* * *} P<0 \cdot 001$ compared with control incubations (without added insulin). $\triangle \triangle P<0 \cdot 01$ compared with GIP at the same concentration.

Villanueva-Peñacarrillo et al. (1994), who found that the other major incretin hormone, tGLP-1, stimulated glycogenic events in rat soleus muscle.

Physiological circulating GIP concentrations in the rat range from approximately $5 \times 10^{-12}$ to $10^{-9} \mathrm{~mol} / 1$ depending on diet (Hampton et al. 1983). Our results on the actions of $10^{-10}$ and $10^{-9} \mathrm{~mol} / \mathrm{l}$ GIP on glucose 
uptake, oxidation, glycogenesis and lactate formation indicate that GIP exerts effects on muscle within the range of reported circulating physiological peptide concentrations. Receptors for GIP have been described in a number of tissues including human insulinomas (Maletti et al. 1986) as well as in endocrine pancreas, stomach, proximal small intestine, adipose tissue, adrenal gland, brain and pituitary (Usdin et al. 1993, Moens et al. 1996) but not to our knowledge in skeletal muscle. Kaplan and Vigna (1994) demonstrated saturable ${ }^{125}$ I-GIP binding to sections of rat brain but were unable to show any radiolabelled-GIP binding to other rat tissues including rat skeletal muscle. Furthermore, others have failed to show any effect of GIP either in the presence or absence of insulin on 2-deoxy-D-glucose uptake in cultured ovine muscle cells (Roe et al. 1995). Taken together these findings tend to suggest that rat skeletal muscle does not contain specific receptors to GIP.

In contrast, our findings suggest that the action of GIP on glucose metabolism in isolated muscle may be as effective as equimolar concentrations of insulin. However, it should be noted that such effects of GIP are probably not recorded in the complete absence of insulin since isolated muscle preparations will potentially contain some residual insulin which could be involved in receptor binding and glycogenic effects. Interestingly, it has been reported (Villanueva-Peöacarrillo et al. 1994) that the direct effect of tGLP-1 on glycogen synthesis in skeletal muscle was similar to the action of insulin, involving an increase in glycogen synthase $a$ activity but no change in glycogen phosphorylase a activity (Marchand-Brustel \& Freychet 1981). Other observations with cultured BC3H-1 myocytes suggest that tGLP-1 may stimulate degradation of glycosyl-phosphatidylinositols into inositolphosphoglycans and diacylglycerol which act as second messengers in muscle tissue (Galera et al. 1996). Further studies are required to evaluate possible involvement of these mechanisms in the actions of GIP in skeletal muscle.

In addition to demonstrating significant glycogenic actions of GIP on muscle for the first time, the present study also indicates that the structurally modified monoglycated peptide (i.e. glucitol adduct of GIP) has a reduced ability to promote glucose uptake and metabolism in this tissue. Other recent studies have shown that the insulin-releasing potency of GIP on clonal BRIN-BD11 cells is also modified by glycation (Abdel-Wahab et al. 1996b). Structure-function studies have indicated that the insulinotrophic effectiveness of GIP is associated with $\mathrm{Tyr}^{1}, \mathrm{Ala}^{2}, \mathrm{Gly}^{4}, \mathrm{Asp}^{9}, \mathrm{Ser}^{11}$ as well as C-terminal portions of the GIP molecule (Maletti et al. 1986, Schmidt et al. 1986, Pedersen et al. 1990, Suzuki et al. 1992). Potential sites of glycation within GIP include the amino-terminal $\mathrm{Tyr}^{1}$ residue as well as five $\varepsilon$-amino groups at Lys residues 16, 30, 32, 33 and 37. Post-translation modification of GIP by glycation at the $\mathrm{NH}_{2}$-terminal or C-terminal regions of the peptide could account for the reduction in biological activity observed here. However, preliminary data obtained from attempted primary sequence determination by automated Edman degradation indicates that the glycated GIP is not modified at the amino terminus (F M O'Harte, J M Conlon \& P R Flatt, unpublished observations) which contrasts with previous findings on the identification of the site of glycation within the insulin B-chain (O'Harte et al. 1996). Consequently, further studies are required to identify the exact locus of glycation within the human GIP molecule.

Recent studies in our laboratory have established that proinsulin and insulin are glycated in the pancreatic B-cells in diabetes (Abdel-Wahab et al. 1996a) and that glycation impairs the glucose lowering activity of insulin in both experimental animals and man (Flatt et al. 1994, Hunter et al. 1996). The present in vitro observations with glycated GIP raise questions concerning possible implications for the physiology of GIP and role in the pathophysiology of non-insulin-dependent diabetes mellitus. Further studies are required to determine the extent of glycation of GIP in the glucose-rich environment of the intestinal endocrine $\mathrm{K}$ cell and the significance of extrapancreatic metabolic actions of GIP.

\section{Acknowledgements}

We thank Dr M Harrison, Finnigan M A T, Hemel Hempstead, UK for carrying out the molecular mass determinations. We thank Dr C J Bailey, Aston University, UK for his advice concerning the use of abdominal muscle preparations. These studies are supported by Northern Ireland Development Research Funding (NIDevR).

\section{References}

Abdel-Wahab YHA, O'Harte FPM, Ratcliff H, McClenaghan NH, Barnett CR \& Flatt PR 1996a Glycation of insulin in the islets of Langerhans of normal and diabetic animals. Diabetes 45 1489-1496.

Abdel-Wahab YHA, O'Harte FPM, Gray AM \& Flatt PR 19966 Glycation of GLP-1(7-36)amide but not GIP reduces its insulinotropic action in vitro. Diabetologia 39 A23.

Abdel-Wahab YHA, O'Harte FPM, Barnett CR \& Flatt PR 1997 Characterization of insulin glycation in insulin-secreting cells maintained in tissue culture. Journal of Endocrinology 152 59-67.

Andersen DK, Elahi D, Brown JC, Tobin JD \& Andres R 1978 Oral glucose augmentation of insulin secretion. Interactions of gastric inhibitory polypeptide with ambient glucose and insulin levels. Journal of Clinical Investigation 62 152-161.

Brown JC, Mutt V \& Pederson RA 1970 Further purification of a polypeptide demonstrating enterogastrone activity. Journal of Physiology 209 57-64.

Cataland S, Crockett SE, Brown JC \& Mazzaferri EL 1974 Gastric inhibitory polypeptide (GIP) stimulation by oral glucose in man. Journal of Clinical Endocrinology and Metabolism 39 223-228.

Delgado E, Luque MA, Alcántara AI, Trapote MA, Clemente F, Galera C, Valverde I \& Villanueva-Peñacarrillo ML 1995 Glucagon-like peptide-1 binding to rat skeletal muscle. Peptides 16 225-229. 
Ebert R, Nuack M \& Creutzfeldt W 1991 Effects of exogenous and endogenous gastric inhibitory polypeptide on plasma triglyceride responses in rats. Hormone and Metabolic Research 23 517-521.

Eckel RH, Fujimoto WJ \& Brunzell JD 1979 Gastric inhibitory polypeptide enhances lipoprotein lipase activity in cultured pre-adipocytes. Diabetes 28 1141-1142.

Elahi D, Meneilly GS, Minaker KL, Rowe JW \& Andersen DK 1986 Regulation of hepatic glucose production by gastric inhibitory polypeptide in man. In Proceedings of the Sixth International Conference on Gastrointestinal Hormones, Vancouver, BC, p 18. Ottawa: National Research Council of Canadian Research Journals.

Fehmann H-C, Göke R \& Göke B 1995 Cell and molecular biology of the incretin hormones glucagon-like peptide-1 and glucosedependent insulin releasing polypeptide. Endocrine Review $\mathbf{1 6}$ 390-410.

Flatt PR, Kwasowski P, Howland RJ \& Bailey CJ 1991 Gastric inhibitory polypeptide and insulin responses to orally administered amino acids in genetically obese hyperglycaemic (ob/ob) mice. Journal of Nutrition 121 1123-1128.

Flatt PR, Abdel-Wahab YHA, Wilson AM, Barnett CR, O'Harte FPM \& Swanston-Flatt SK 1994 Site-specific defects and glucose toxicity in pancreatic B-cell dysfunction of non-insulin dependent diabetes mellitus. In Frontiers of Insulin Secretion and Pancreatic B-cell Research, pp 481-489. Eds PR Flatt \& S Lenzen. London: Smith-Gordon \& Co. Ltd.

Galera C, Clemente F, Alcántara A, Trapote MA, Perea A, López-Delgado MI, Villanueva-Peñacarrillo ML \& Valverde I 1996 Inositolphosphoglycans and diacylglycerol are possible mediators of the glycogenic effect of GLP-1(7-36)amide in BC3H-1 myocytes. Cell Biochemistry and Function 14 43-48.

Hampton SM, Kwasowski P, Tan K, Morgan LM \& Marks V 1983 Effect of pre-treatment of a high fat diet on the gastric inhibitory polypeptide and insulin responses to oral triolein and glucose in rats. Diabetologia 24 278-281.

Hartmann H, Ebert R \& Creutzfeldt W 1986 Insulin-dependent inhibition of hepatic glycogenolysis by gastric inhibitory polypeptide (GIP) in perfused rat liver. Diabetologia 29 112-114.

Hunter SJ, Wiggam MI, Boyd AC, O'Harte FPM, Ennis CN, Gamble R, Sheridan B, Barnett CR, McNulty H, Bell PM \& Flatt PR 1996 Glycation of human insulin reduces its biological potency as assessed by euglycaemic clamps in normal man. Diabetic Medicine 13 (Suppl 7) S17 (Abstract).

Kaplan AM \& Vigna SR 1994 Gastric inhibitory polypeptide (GIP) binding sites in rat brain. Peptides 15 297-302.

Krarup T, Holst JJ \& Larsen KL 1985 Responses and molecular heterogeneity of IR-GIP after intraduodenal glucose and fat. American Journal of Physiology 249 E195-E200.

Kwasowski P, Flatt PR, Bailey CJ \& Marks V 1985 Effect of fatty acid chain length and saturation on gastric inhibitory peptide release in obese hyperglycaemic (ob/ob) mice. Bioscience Reports 5 701-705.

Maletti M, Portha B, Hoa DHB, Carlquist M \& Rosselin G 1986 Evidence of functional gastric inhibitory polypeptide (GIP) receptors in human insulinoma. Binding of synthetic human GIP 1-31 and activation of adenylate cyclase. Diabetes 36 1336-1340.

Marchand-Brustel YM \& Freychet P 1981 Regulation of glycogen synthase activity in the isolated mouse soleus muscle. Effect of insulin, epinephrine, glucose and anti-insulin receptor antibodies. Biochimica et Biophysica Acta 677 13-22.

Maxwell V, Shulkes A, Brown JC, Solomon TE, Walsh JH \& Grossman MI 1980 Effect of gastric inhibitory polypeptide on pentagastrin-stimulated acid secretion in man. Digestive Diseases and Science 25 113-116.

Moens K, Heimberg H, Flamez D, Huypens P, Quartier E, Ling Z, Pipeleers D, Gremlich S, Thorens B \& Schuit F 1996 Expression and functional activity of glucagon, glucagon-like peptide 1 , and glucose-dependent insulinotropic peptide receptors in rat pancreatic islet cells. Diabetes 45 257-261.
Morgan LM 1996 The metabolic role of GIP: physiology and pathology. Biochemical Society Transactions 24 585-591.

Morgan LM, Flatt PR \& Marks V 1988 Nutrient regulation of the entero-insular axis and insulin secretion. Nutrition Research Review $\mathbf{1}$ 79-97.

Nauck MA, Bartels E, Orskov C, Ebert R \& Creutzfeldt W 1992 Lack of effect of synthetic human gastric inhibitory polypeptide and glucagon-like peptide-1(3-36)amide infused at near physiological concentrations on pentagastrin-stimulated gastric acid secretion in normal human subjects. Digestion 52 214-221.

Oben J, Morgan L, Fletcher J \& Marks V 1991 Effect of the entero-pancreatic hormones gastric inhibitory polypeptide and glucagon-like peptide-1(7-36)amide on fatty acid synthesis in explants of rat adipose tissue. Journal of Endocrinology 130 267-272.

O'Harte FPM, Höjrup P, Barnett CR \& Flatt PR 1996 Identification of the site of glycation of human insulin. Peptides 17 1323-1330.

O'Harte FPM, Gray AM, Abdel-Wahab YHA \& Flatt PR 1998 Effects of non-glycated and glycated glucagon-like peptide-1(7-36) amide on glucose metabolism in isolated mouse abdominal muscle. Peptides 18 (In Press).

Pedersen RA 1994 Gastric inhibitory polypeptide. In Gut Peptides: Biochemistry and Physiology, pp 217-259. Eds JH Walsh \& GJ Dockray. New York: Raven Press Ltd.

Pedersen RA, Mochizuki T, Yanaihara C, Yanihara N \& Brown JC 1990 Dissociation of the somatostatinotropic and insulinotropic actions of GIP by fragments of $\mathrm{GIP}_{[1-30]}-\mathrm{NH}_{2}$ and $\mathrm{GIP}_{[1-30]} \mathrm{OH}$. Digestion 4686.

Penman E, Wass JAH, Medbank S, Morgan LM, Lewis J, Besser GM \& Rees LH 1981 Response of circulating somatostatin to nutritional stimuli in normal subjects. Gastroenterology 81 692-699.

Roe JA, Baba ASH, Harper JMM \& Buttery PJ 1995 Effects of growth factors and gut regulatory peptides on nutrient uptake in ovine muscle cell cultures. Comparative Biochemistry and Physiology 110 107-114.

Schmidt WE, Siegel EG, Ebert R \& Creutzfeldt W 1986 N-terminal tyrosine-alanine is required for the insulin releasing activity of glucose-dependent insulinotropic polypeptide. European Journal of Clinical Investigation 16 A9.

Suzuki S, Kawai K, Ohashi S, Watanabe Y \& Yamashita K 1992 Comparison of the insulinotropic activity of the glucagonsuperfamily peptides in rat pancreas perfusion. Hormone and Metabolic Research 24 458-461.

Sykes S, Morgan LM, English J \& Marks V 1980 Evidence for preferential stimulation of gastric inhibitory polypeptide secretion in the rat by actively transported carbohydrates and their analogues. Journal of Endocrinology 85 201-207.

Usdin TB, Mezey E, Button DC, Brownstein MJ \& Bonner TI 1993 Gastric inhibitory polypeptide receptor, a member of the secretin vasoactive polypeptide receptor family, is widely distributed in peripheral organs and the brain. Endocrinology 133 2861-2870.

Villanueva-Peñacarrillo ML, Alcantara AL, Clemente F, Delgado E \& Valverde I 1994 Potent glycogenic effect of GLP-1(7-36)amide in rat skeletal muscle. Diabetologica 37 1163-1166.

Wheeler MB, Gelling RW, McIntosh CHS, Georgioi J, Brown J \& Pedersen RA 1995 Functional expression of the rat pancreatic islet glucose-dependent insulinotropic polypeptide receptor: ligand binding and intracellular signalling properties. Endocrinology 136 4629-4639.

Received 27 March 1997

Revised manuscript received 14 July 1997

Accepted 26 August 1997 